\title{
Studies on Hydrodesulfurization of Heavy Distillates (Part 3)
}

\author{
Physical and Chemical Properties of Product Oils
}

\author{
Toshiaki Hisamitsu* and Hiromi OzaKi \\ Gentral Research Laboratories, Nippon Mining Co., Ltd., \\ 3-17-35, Niizo-Minami, Toda, Saitama 335 \\ (Received September 12, 1985)
}

\begin{abstract}
Vacuum gas oil was hydroprocessed over a $\mathrm{Co}-\mathrm{Mo}-\mathrm{Al}_{2} \mathrm{O}_{3}$ catalyst at temperatures of 380 , 400 , and $420^{\circ} \mathrm{C}$ and at pressures of 4.0 and $7.9 \mathrm{MPa}$. The physical and chemical properties of the product oils, viz., middle distillate and vacuum gas oil fractions were correlated. Also the properties of these oils were correlated with reaction conditions and with the results of cracking, desulfurization, and denitrogenation conversions. It was expected that the middle distillate produced by mild hydrocracking of vacuum gas oil would be less suitable as fuel oil and that the vacuum gas oil fraction in the product is a suitable feedstock for such upgrading process as fluidized catalytic cracking.
\end{abstract}

\section{Introduction}

In our preceding paper ${ }^{1)}$ we reported the results of the kinetics of hydrocracking $(\mathrm{HC})$, hydrodesulfurization(HDS), and hydrodenitrogenation(HDN) reactions involved in the hydroprocessing of vacuum gas oil under rather severe reaction conditions as compared to those in the conventional indirect HDS reaction. To evaluate mild hydrocracking (MHC) process as a means of increasing conversion of vacuum gas oil into middle distillate by utilizing the existing indirect HDS facilities, detailed data on the properties of not only middle distillate but also of vacuum gas oil, and also data on reaction kinetics will be necessary.

Concerning the properties of the product oil produced by $\mathrm{MHC}$ process, attention is focused mostly on the smoke point, cetane number, aniline point of the middle distillate fraction. The smoke point of kerosene and cetane number of the middle distillate are reported to be about $12 \mathrm{~mm}$ and $40-55$, respectively. ${ }^{2}$,3) Cetane number increases with increasing boiling point, and cetane number 43 for the fraction boiling between 243 and $321^{\circ} \mathrm{C}$ increases to 53 for the fraction boiling between 321 and $360^{\circ} \mathrm{C}^{3}$ ) Also the cetane number of the fraction boiling between 166 and $343^{\circ} \mathrm{C}$ increases from 37 to 41 by removing the lighter fractions boiling below $249^{\circ} \mathrm{C}^{2}$ ) As regards to $\mathrm{MHC}$ process, available information on the correlation between

\footnotetext{
* To whom correspondence should be addressed
}

reaction conditions and properties especially of the vacuum gas oil fraction remaining unconverted is limited.

This paper deals with the physical and chemical properties of the middle distillate and vacuum gas oil fractions obtained from the hydroprocess studies reported in the preceding paper.

\section{Experimentals}

Hydroprocessing of vacuum gas oil was carried out over a Co- $\mathrm{Mo}-\mathrm{Al}_{2} \mathrm{O}_{3}$ catalyst at temperatures of 380,400 , and $420^{\circ} \mathrm{C}$ and at pressures of 4.0 and $7.9 \mathrm{MPa}$. Experimental details have been described in the preceding paper.1)

\subsection{Elemental Analysis}

Hydrogen and carbon contents were determined with a CHN-analyzer using a Perkin-Elmer model 240-C.

\subsection{Physical Properties}

Specific gravity, viscosity, refractive index were determined according to the procedures of JISK2249, JIS-K2283, and JIS-C2101, respectively. Specific gravity and refractive index were determined at $20^{\circ} \mathrm{C}$ for Middle Distillate and at $50^{\circ} \mathrm{C}$ for Vacuum Gas Oil.

\subsection{Aromatic Carbon Content}

The ratio of the aromatic carbon content to the total carbon content, $\mathrm{C}_{\mathrm{a}}$, in Middle Distillate and Vacuum Gas Oil was determined according to the n-d-M method.4),5) 


\section{Results and Discussion}

The properties of the feedstock and the whole range of product oil (Whole Product Oil) obtained by hydroprocessing, and the properties of the two fractions, Middle Distillate (b.p. 182 to $360^{\circ} \mathrm{C}$ ) and Vacuum Gas Oil (b.p. $>360^{\circ} \mathrm{G}$ ), separated from the feedstock and Whole Product Oil, except for the data already reported in the preceding paper, are summarized in Table 1.

\subsection{Whole Product Oil}

Specific gravity and viscosity of Whole Product Oil were plotted as a function of the reciprocal of LHSV in Figs. 1 and 2, respectively. With increasing $1 / \mathrm{LHSV}$, both the specific gravity and viscosity decrease, however, with different rates depending on the reaction temperature and pressure. As shown in Fig. 1, the curves of $400^{\circ} \mathrm{C}$ at 4.0

Table 1 Experimental Results

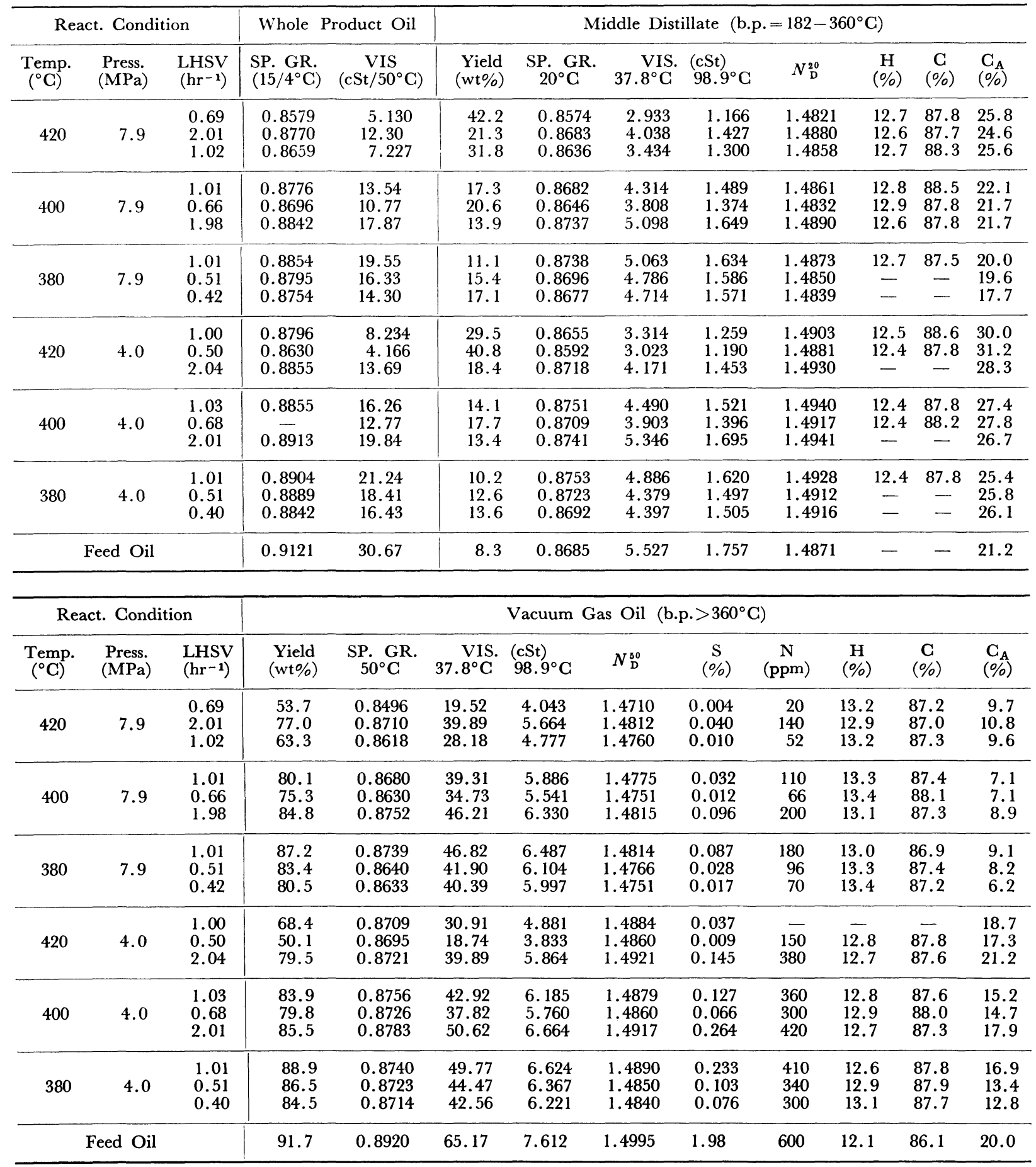




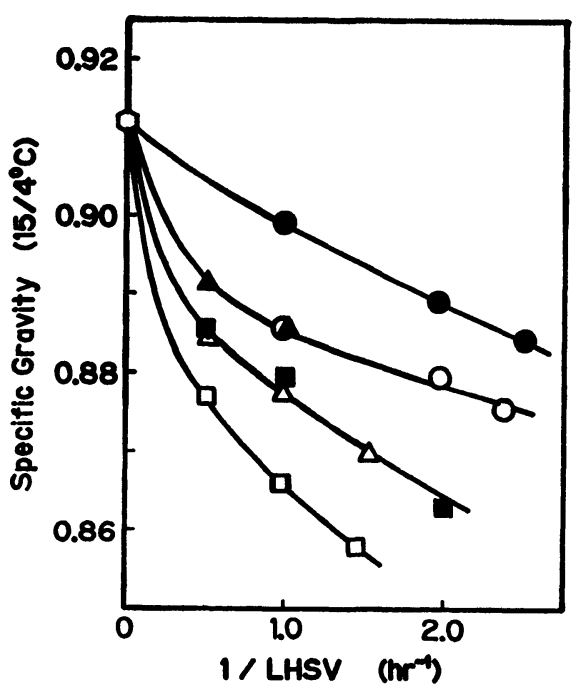

$\mathrm{O}: 380^{\circ} \mathrm{C}, \triangle: 400^{\circ} \mathrm{C}, \square: 420^{\circ} \mathrm{C}$

Solid : $4.0 \mathrm{MPa}$, Open : $7.9 \mathrm{MPa}$

Fig. 1 Specific Gravity of Whole Product Oil vs. 1/ LHSV

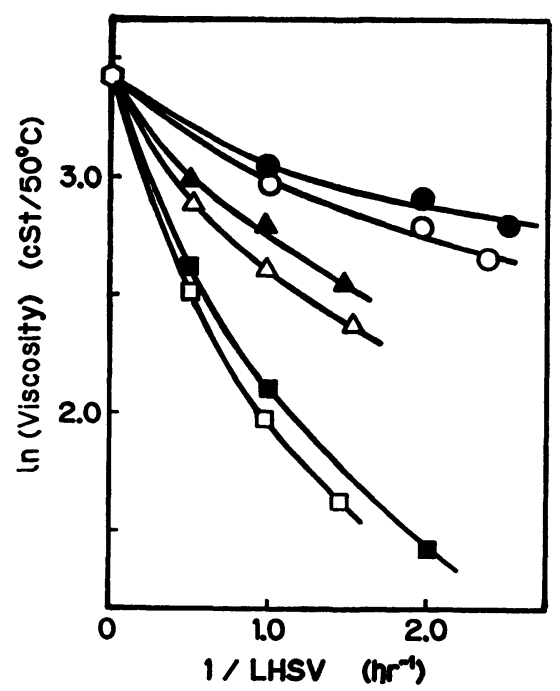

(symbols the same as for Fig. 1)

Fig. 2 Viscosity of Whole Product Oil vs. 1/LHSV

$\mathrm{MPa}$ and $380^{\circ} \mathrm{C}$ at $7.9 \mathrm{MPa}$ and the curves of $420^{\circ} \mathrm{C}$ at $4.0 \mathrm{MPa}$ and $400^{\circ} \mathrm{C}$ at $7.9 \mathrm{MPa}$ overlap with each other. Accordingly, the effect of increasing the pressure from 4.0 to $7.9 \mathrm{MPa}$ on specific gravity is nearly equal to the effect of increasing the temperature by $20^{\circ} \mathrm{C}$. As reported in the preceding paper, ${ }^{1)}$ the effect of pressure on specific gravity is simular to that observed on the sulfur content of Whole Product Oil. This is confirmed by the fact that sulfur removal correlates closely with the decrease in specific gravity independently of pressure and temperature, as shown in Fig. 3. If changes in specific gravity and sulfur removal are differently affected by pressure, the curve shown in Fig. 3 would separate into two

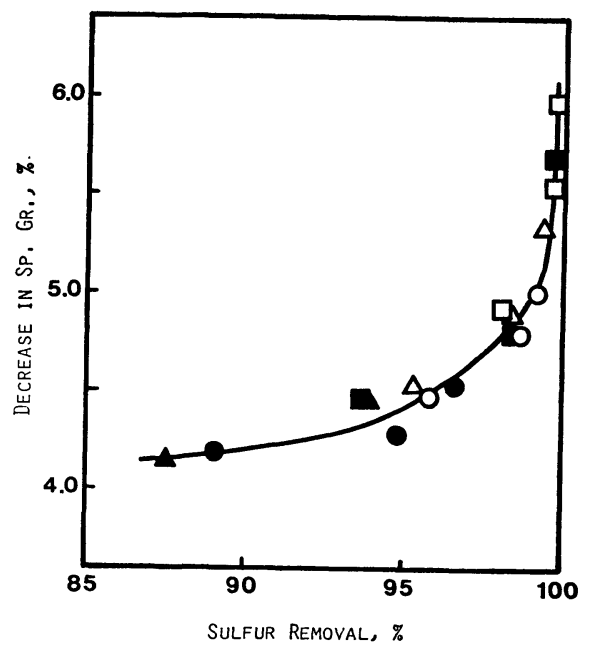

(symbols the same as for Fig. 1)

Fig. 3 Decrease in Specific Gravity vs. Sulfur Removal in Whole Product Oil

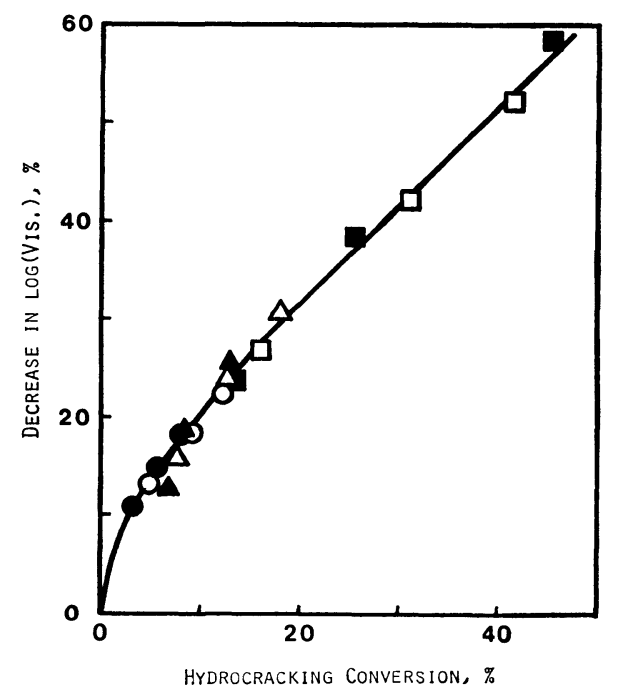

(symbols the same as for Fig. 1)

Fig. 4 Decrease in Viscosity in Whole Product Oil vs. Hydrocracking Conversion

curves for 4.0 and $7.9 \mathrm{MPa}$ as observed in the relationship between sulfur and nitrogen removals.

While the effect of pressure on decreasing the viscosity seems to be relatively small, the effect of pressure on hydrocracking conversion was likewise small as reported in the preceding paper. ${ }^{1)}$ This is supported by the fact that, as shown in Fig. 4, the decrease in viscosity and that in hydrocracking conversion are also correlated by a single curve independent of pressure and temperature.

On the other hand, the nitrogen and sulfur removals are correlated with two curves distinguished by pressure difference as shown in Fig. 5. This is consistent with the concept that HDS and HDN reactions are affected differently by pressure. As 
reported in the preceding paper, the effect on the sulfur and nitrogen contents of Whole Product Oil of increasing the pressure from 4.0 to $7.9 \mathrm{MPa}$ corresponded to increasing the temperature by 20 and $40^{\circ} \mathrm{C}$, respectively.

Furthermore, Figure 6 shows that the relationship between sulfur removal and hydrocracking conversion is affected differently by temperature and pressure. In other words, HDS and $\mathrm{HC}$ reactions are affected differently by pressure and temperature. The same relationship observed above is also expected to exist between nitrogen removal and hydrocracking conversion, because the nitrogen removal is correlated with that of sulfur

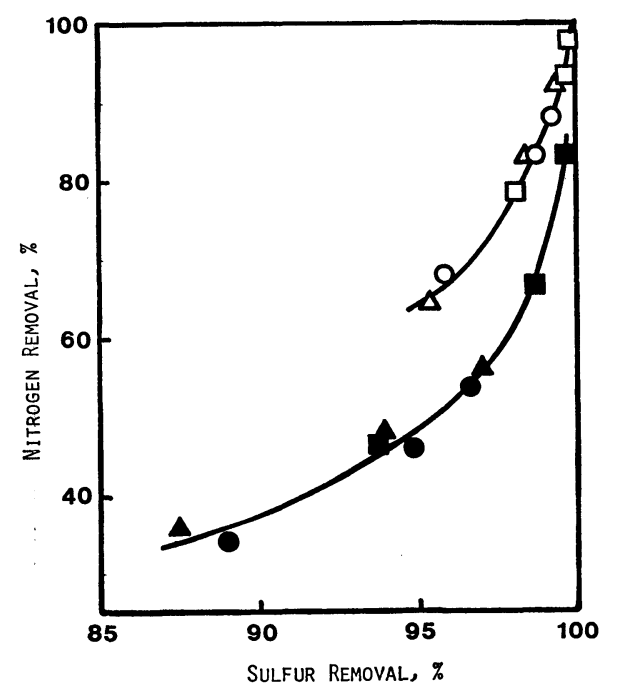

(symbols the same as for Fig. 1)

Fig. 5 Nitrogen Removal vs. Sulfur Removal in Whole Product Oil

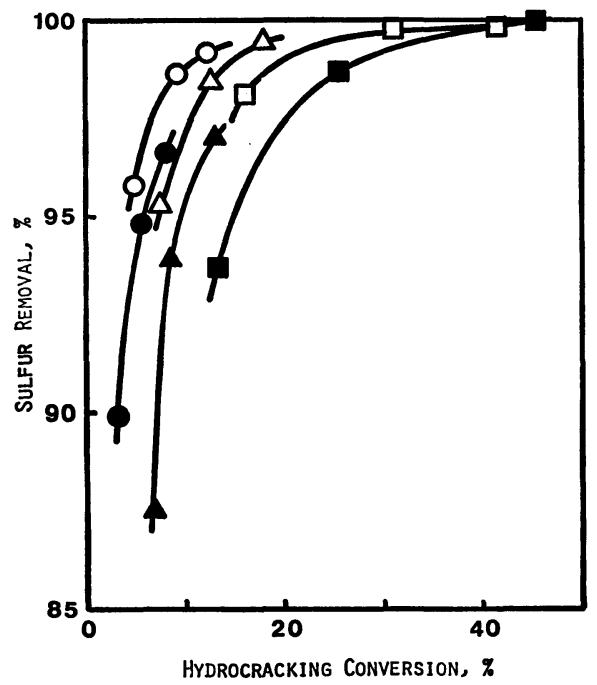

(symbols the same as for Fig. 1)

Fig. 6 Sulfur Removal in Whole Product Oil vs. Hydrocracking Conversion independent of temperature as shown in Fig. 5. This is consistent with the concept described in the preceding paper, ${ }^{1)}$ that $\mathrm{HC}$ reaction proceeds through two mechanisms which are different from each other : one, like HDS and HDN both of which take place only on the catalyst surface, and the other that takes place by thermal cracking in absence of a catalyst. The results shown in Fig. 6 also indicate that hydrocracking conversion increases with increasing temperature even when the sulfur content is kept constant by increasing LHSV or decreasing pressure to cancel the effect of increasing temperature.

\subsection{Middle Distillate}

The ratio of the aromatic carbon content to the total carbon content $\left(\mathrm{C}_{\mathrm{a}}\right)$ in Middle Distillate is plotted as a function of the reciprocal of LHSV in Fig. 7. $\mathrm{C}_{\mathrm{a}}$ varies with change in $1 / \mathrm{LHSV}$, and it is higher at higher temperature and at lower pressures ; $\mathrm{C}_{\mathrm{a}}$ for $380^{\circ} \mathrm{C}$ at $4.0 \mathrm{MPa}$ is almost equal to that for $420^{\circ} \mathrm{C}$ at $7.9 \mathrm{MPa}$. It is known that the equilibrium state between hydrogenation of aromatic rings and dehydrogenation of naphthenic rings shifts toward dehydrogenation as temperature increases and also as hydrogen pressure decreases. Therefore, the effect of increasing the temperature from 380 to $420^{\circ} \mathrm{C}$ on the equilibrium state is just about canceled by the reverse effect of increasing the pressure from 4.0 to $7.9 \mathrm{MPa}$.

The $\mathrm{C}_{\mathrm{a}}$ of hydroprocessed Middle Distillate varies in the range from 17.7 to $25.8 \%$ at $7.9 \mathrm{MPa}$ and from 25.4 to $31.2 \%$ at $4.0 \mathrm{MPa}$. Most of these values are higher than $21.2 \%$ for Middle Distillate separated from the feedstock. Accordingly, it is

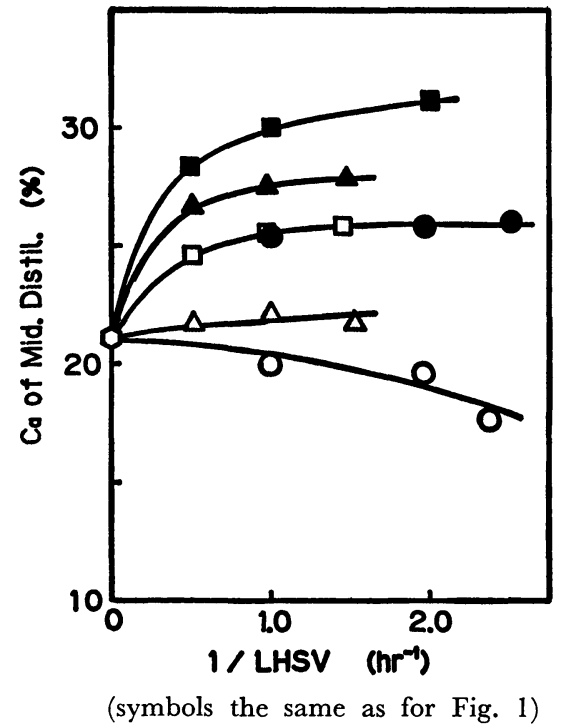

Fig. $7 \mathrm{Ca}$ of Middle Distillate vs. 1/LHSV 
anticipated that the smoke point and cetane number of Middle Distillate produced by MHC process are low in comparison to those of corresponding straightrun fractions obtained from the Middle Eastern crude oil.

Although not all of the Middle Distillate samples were subjected to hydrogen analysis, the hydrogen content does not seem to be sensitive to changes in reaction conditions compared to $\mathrm{C}_{\mathrm{a}}$. The hydrogen content is between 12.6 and $12.9 \mathrm{wt} \%$ for Middle Distillate obtained at 7.9 MPa and between 12.4 and $12.5 \mathrm{wt} \%$ for that at $4.0 \mathrm{MPa}$, as shown in Table 1.

In the present study, Middle Distillate boiling between 182 and $360^{\circ} \mathrm{C}$ was collected as a single fraction without separating it into kerosene and diesel fuel oil because of the low yields of Middle Distillate for some product oils obtained under milder reaction conditions. Therefore, the properties of the Middle Distillates separated form the feedstock and that separated from Whole Product Oil were not strictly comparable, because the former consisted of only a diesel fuel oil fraction, while the latter contained both kerosene and diesel fuel oil fractions.

\subsection{Vacuum Gas Oil}

Figure 8 shows the relationship between $\mathrm{C}_{\mathrm{a}}$ in Vacuum Gas Oil and 1/LHSV. Comparing the effect of pressure on its $\mathrm{C}_{\mathrm{a}}$ with that on $\mathrm{C}_{\mathrm{a}}$ in Middle Distillate, pressure seems to have a greater effect on $\mathrm{C}_{\mathrm{a}}$ in Vacuum Gas Oil. However, the effect of temperature is rather unclear. $\mathrm{C}_{\mathrm{a}} \mathrm{s}$ for $420^{\circ} \mathrm{G}$ and $400^{\circ} \mathrm{C}$ almost level off at $1 / \mathrm{LHSV}$ higher than 1.0, while, $\mathrm{C}_{\mathrm{a}}$ for $380^{\circ} \mathrm{C}$ continues to decrease and

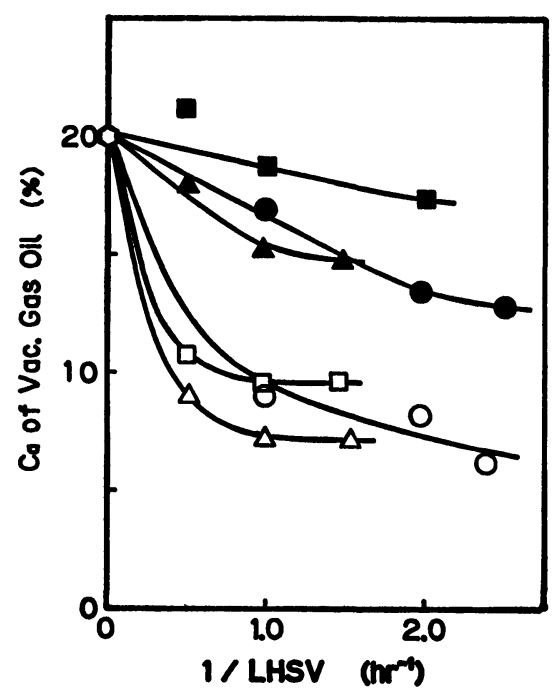

(symbols the same as for Fig. 1)

Fig. $8 \mathrm{Ca}$ of Vacuum Gas Oil vs. 1/LHSV

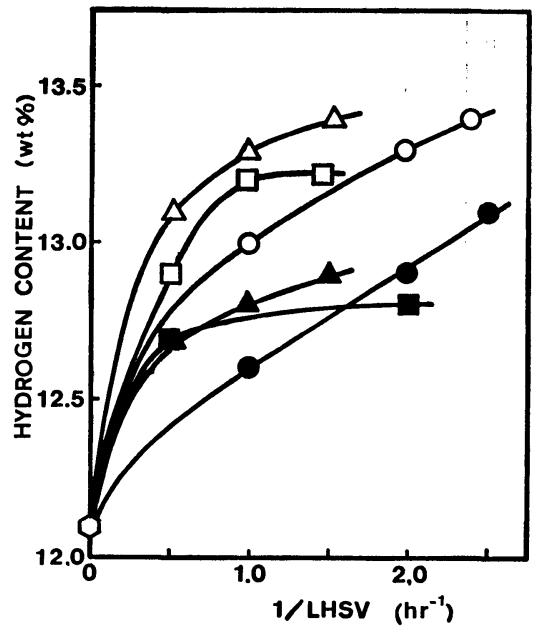

Fig. 9 Hydrogen Content of Vacuum Gas Oil vs. 1/ LHSV

acrosses the line for $400^{\circ} \mathrm{C}$ with further increase in $1 /$ LHSV. This may imply that the reaction rates of hydrogenation and dehydrogenation attain an equilibrium state at 400 and $420^{\circ} \mathrm{C}$ at $1 / \mathrm{LHSV}$ about 1.0 , but the reaction rate at $380^{\circ} \mathrm{C}$ is too slow to attain an equilibrium state even at $1 / \mathrm{LHSV}$ of 2.5.

Figure 9 shows the plots of hydrogen content of Vacuum Gas Oil vs. 1/LHSV. With increase in $1 /$ LHSV, the hydrogen content increases with different rates in the range from 12.9 to $13.4 \mathrm{wt} \%$ at $7.9 \mathrm{MPa}$ and from 12.6 to $13.1 \mathrm{wt} \%$ at $4.0 \mathrm{MPa}$ depending on temperature. Although the hydrogen content varies within a rather narrow range, the change in hydrogen content coincides with the change in $\mathrm{C}_{\mathrm{a}}$ shown in Fig. 8. And the atomic ratio of hydrogen to carbon, $H / C$, correlates satisfactorily with $\mathrm{C}_{\mathrm{a}}$ except for the feedstock, as shown in Fig. 10. This disparity of the feedstock indicates that part of the hydrogen consumed by hydroprocessing is taken into the product oil without decreasing $\mathrm{C}_{\mathrm{a}}$. This observation may be attributable to the hydrogenolysis of aliphatic carbon-sulfur bond and aliphatic carbon-nitrogen bond. Such hydrogenolysis is known to take place relatively easily and proceeds in the early stages of reaction. In addition, the decrease in $\mathrm{C}_{\mathrm{a}}$ and the increase in hydrogen content imply that hydroprocessed Vacuum Gas Oil consists of more paraffinic and naphthenic molecules than the feedstock and that hydroprocessed Vacuum Gas Oil may be suitable as a feedstock for fluidized catalytic cracking.

Many studies on HDN reaction mechanism of polynuclear heterocyclic nitrogen compounds such as quinoline, ${ }^{6), 7)}$ indole,${ }^{8)}$ carbazole,${ }^{9)}$ and acri- 


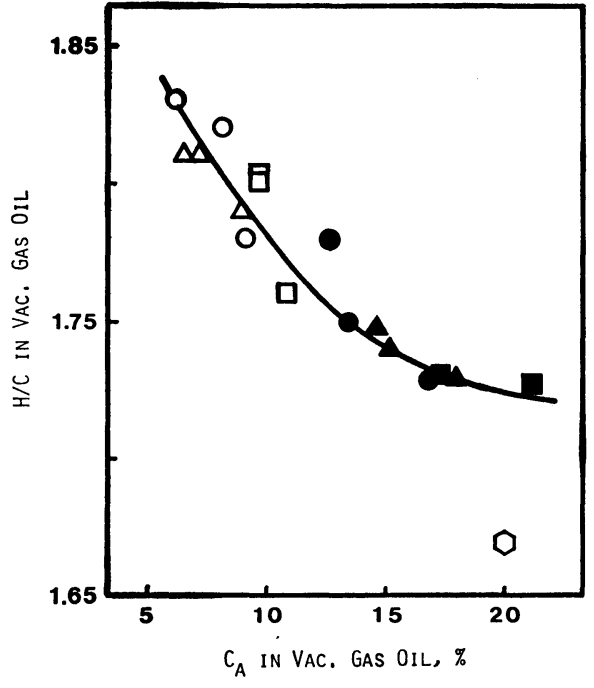

(symbols the same as for Fig. 1)

Fig. 10 Hydrogen/Carbon Atomic Ratio vs. Aromatic Carbon Content in Vacuum Gas Oil

ine $^{10)}$ have been reported. It is generally accepted that HDN of those compounds apparently consumes a much larger amount of hydrogen than does HDS of the homologous heterocyclic sulfur compounds, because not only the heterocyclic rings but also the adjacent aromatic rings have to be hydrogenated prior to the hydrogenolysis of the nitrogen-carbon bonds. Accordingly, it might be expected that there is some relationship between nitrogen content and $\mathrm{C}_{\mathrm{a}}$ or $\mathrm{H} / \mathrm{C}$ of the product oil. Figures 11 and 12 show the plots of nitrogen removal as a function of $\mathrm{C}_{\mathrm{a}}$ and $\mathrm{H} / \mathrm{C}$, respectively. As shown in these figures, nitrogen removal seems to be well correlated with $\mathrm{C}_{\mathrm{a}}$ and $\mathrm{H} / \mathrm{C}$ at 380 and $400^{\circ} \mathrm{C}$ regardless of pressure. However, the plot for $420^{\circ} \mathrm{C}$ deviates significantly from these correlations toward higher $\mathrm{C}_{\mathrm{a}}$ and lower $\mathrm{H} / \mathrm{C}$. This may indicate that dehydrogenation reaction of the naphthenic rings becomes significant at $420^{\circ} \mathrm{C}$ due to the shift of the equilibrium state toward higher aromaticity and that the contribution of dealkylation reaction to increasing aromaticity is also considered significant.

\section{Conclusions}

The results of the present study on the properties of the product oil obtained from mild hydrocracking of vacuum gas oil are summarized as follows;

(1) Concerning the properties of the whole range of product oil there exist a good correlation between decrease in viscosity and hydrocracking conversion and also a good correlation between de-

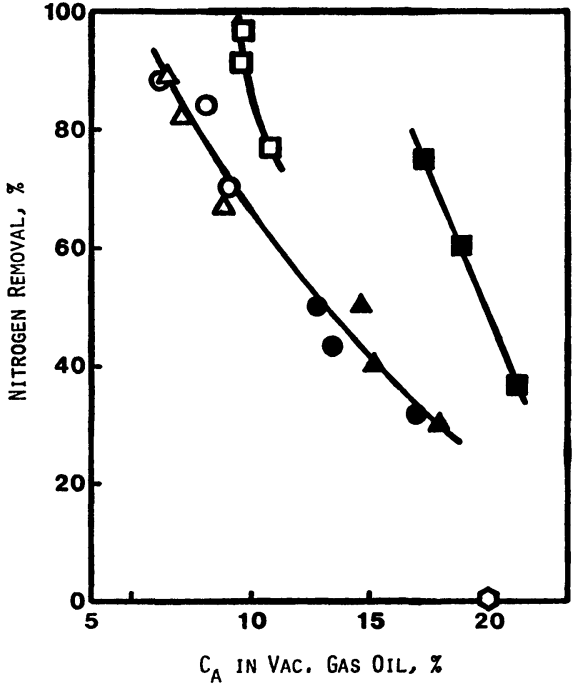

(symbols the same as for Fig. 1)

Fig. 11 Nitrogen Removal vs. Aromatic Carbon Ciontent in Vacuum Gas Oil

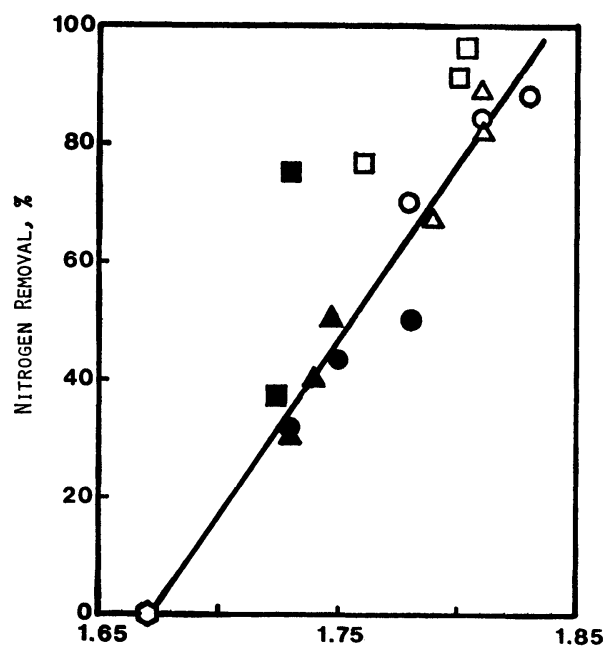

H/C IN VAC, GAS OIL

(symbols the same as for Fig. 1)

Fig. 12 Nitrogen Removal vs. Hydrogen/Carbon Atomic Ratio in Vacuum Gas Oil

crease in specific gravity and sulfur removal; both correlation are independent of temperature and pressure.

(2) Compared to the corresponding straight-run fractions produced from Middle Eastern crude oils, the middle distillate fraction produced contains an appreciably higher amount of aromatic carbon, and the fraction is expected to have a lower smoke point and cetane number.

(3) The unconverted vacuum gas oil, which contains less aromatic carbon and more hydrogen than the feedstock, seems to be a suitable feedstock for fluidized catalytic cracking. 


\section{References}

1) Hisamitsu, T., Ozaki, H., Sekiyu Gakkaishi, 29, 295(1986).

2) Gembicki, V. A., Andermann, R. E., Tajbl, D. G., Oil Gas J., 116, Feb. 21 (1983).

3) Billon, A., Bigeard, P. H., Morel, F., Peries, J. P., Paper presented to Petrol. Refin. Cong. of Japan Petrol. Inst., Nov. 15-16 (1982).

4) Fujita, M., Ed. by Funasaka, W., "Nenryo Bunseki Shikenho", 457(1968), Nankodo, Tokyo.
5) Van Nes, K., "Aspects of the Constitution of Mineral Oils", 334(1951), Elsevia, New York.

6) Aboul-Gheit, A. K., Can. J. Chem., 53, 2575 (1975)

7) Satterfield, C. N., Cocchetto, J. F., Ind. Eng. Chem. Process Des. Dev., 20, 53 (1981).

8) Stern, E. W., J. Catal., 57, 390 (1979).

9) Nagai, M., Sawahiraki, K., Kabe, T., Nippon Kagaku Kaishi, 1979, 69.

10) Nagai, M., Sawahiraki, K., Kabe, T., Nippon Kagaku Kaishi, 1979, 1350.

要

\title{
重質留出油の水素化脱硫の研究（第 3 報） 生成油の物理的およひ化学的性状
}

\author{
久光 拨昭，尾崎 博己
}

日本釷業(株)総合研究所, 335 埼玉県戸田市新曽南 3-17-35

前報にて報告した中東系減圧軽油の水素化精製油を分留して 得た中間留分と減圧軽油留分の物理的, 化学的性状相互間の関 連性, およびこれらの性状と反応条件, さらには分解, 脱硫, 脱窒素の転化率との関連性について検討した。

反応温度と圧力が比重および粘度の変化に及ぼす影響の大き さは, おのおの脱硫率と分解率への影響の大きさとほほ等しい (Figs. 1, 2)。従って, 生成油の比重と硫黄含量の減少率 (Fig. 3), および粘度减少率と分解率 (Fig. 4) との間には, 反応温 度や反応王力の影響を受けない良い相関がある。脱硫率と脱窒 素率との相関は (Fig. 5), 反応温度では变化しないが, 反応 圧力の影響は受ける。一方, 脱硫率と分解率の 関係は (Fig. 6), 反応温度および反応圧力のいずれが变化しても変わる。脱 窒素率と分解率の関係についても，同じことがいえる。

生成油に含まれる中間留分, 減圧軽油留分中の芳香族炭素含
量 $\left(\mathbf{C}_{\mathrm{a}}\right)$ の变化も, 反応温度と反応圧力の両者の影響を受ける (Figs. 7, 8)。原料油に含まれる中間留分, および減圧軽油留 分と比較すると, 生成油中の $\mathrm{C}_{\mathrm{a}}$ は, ほとんどの中間留分にお いて增加しているのに対し, 減圧軽油留分では減少している。 また, 減圧軽油留分の水素含量は $\mathbf{C}_{\mathrm{a}}$ の变化と良く相関して おり，いずれの条件においても原料油よりも高くなっている

(Figs. 9, 10)。従って, 減圧軽油のマイルド・ハイドロクラ ッキングで生成する中間留分の燃料油としての性状は, 直留油 より劣るが, 減圧軽油留分は, 接触分解等の二次処理の原料油 として適していると考えられる。

脱窒素率は反応温度が $420^{\circ} \mathrm{C}$ と高い場合を除き， $\mathrm{C}_{\mathrm{a}}$ および $\mathrm{H} / \mathrm{C}$ のいずれとも良い相関を示す (Figs. 11, 12)。420C で は，芳香性の高い方向へ平衡が移動することの影響が大きいた め，前記の相関からはずれると考えられる。

\section{Keywords}

Aromaticity, Cobalt molybdenum catalyst, Heavy distillate, Mild hydrocracking, Product oil property 